Available online at GSC Online Press Directory

GSC Biological and Pharmaceutical Sciences

e-ISSN: 2581-3250, CODEN (USA): GBPSC2

Journal homepage: https://www.gsconlinepress.com/journals/gscbps

(RESEARCH ARTICLE)

\title{
The control of clinical pneumonia in calves
}

\author{
Farkhad Hoshyar Babak ${ }^{1,}{ }^{*}$, Khanzade Javad ${ }^{1}$ and Montazemi Peyman ${ }^{2}$ \\ ${ }^{1}$ Graduated of veterinary medicine, Faculty of veterinary medicine, Tabriz Branch, Islamic Azad University, Tabriz, Iran. \\ 2 Private veterinary medicine, Iran.
}

Publication history: Received on 24 September 2019; revised on 04 May 2019; accepted on 08 May 2019

Article DOI: https://doi.org/10.30574/gscbps.2019.9.1.0106

\begin{abstract}
In feedlot, the respiratory disease is the most common problems. The use of an appropriate antibiotic in the treatment of respiratory disease is an important consideration to the feedlot owner and his veterinarian. The aim of this study was to investigate the effects of penicillin in treatment of calves pneumonia. In this study, forty calves of 3-6 months of age with an average weight of 60 to $100 \mathrm{~kg}$ with pneumonia were clinically examined. Understudied calves were distributed in two groups, in control group for treatment penicillin was used, and the other group was kept as control. During the treatment phase of patients with pneumonia in control and experimental group, sterile swabs was taken from the lower part of the urt of infected patients, and simultaneous with antibiotic therapy, the taken sterile swabs were undergoes bacteriological examination and types of bacteria was characterized. Statistical results indicated that the treatment with penicillin decrease clinical signs significantly in comparison to control one $(\mathrm{p}<0.05)$. The results indicated that the penicillin procaine injection powder ( 3 million iu) might be effective in the treatment of pneumonia in calves with the effective range.
\end{abstract}

Keywords: Pneumonia, calves, antibiotic sensitivity, penicillin

\section{Introduction}

Calfhood diseases have a major impact on the economic viability of cattle operations, due to the direct costs of calf losses and treatment and the long-term effects on performance [1]. Furthermore, calf health was prioritized as one of the most important animal health issues facing the livestock industry. Respiratory disease is the most common cause of sickness and mortality in the feedlot [2,3]. The selection of an appropriate antibiotic and the evaluation of its success in the treatment of respiratory disease is an important consideration to the feedlot owner and his veterinarian. Many antimicrobials have been used in the treatment of respiratory disease and have been evaluated to some extent [4]. Initial field trials with a potentiated sulfonamide suggested a high level of efficacy in the treatment of bacterial diseases of cattle and pigs [5]. In this study, we compared the efficacy of penicillin (3 million IU) in the treatment of calves respiratory disease.

Penicillin had a significant bactericidal effects, especially affects on gram-positive but mostly it is ineffective on gramnegative bacteria. Some of the bacteria with the 0.07 units of penicillin per $\mathrm{ml}(\mathrm{ml})$ will stop growing, include Clostridium perferingens, Clostridium tetany, Staphylococcus aureus, Streptococcus agalactiae, and Corynebacterium pyogenes [6]. Another group of bacteria, which the above amount of penicillin does not inhibit, the growth of them are Gram-negative bacilli and includes following: Escherichia coli, Salmonella, Klebsiella, the Proteus spp. and Pseudomonas spp., which are very resistant to it. When penicillin is comparing with tetracycline or other broad-spectrum antibiotics, it should be consider the relatively narrow range of the spectrum but important antibacterial range of penicillin [7].

\footnotetext{
${ }^{*}$ Corresponding author

E-mail address: drdvm09@gmail.com
} 
Penicillin is usually ineffective in mammalian because the mammalian cells are without rigid cell walls specific for bacteria. Most penicillin which are in water suspended when injected intramuscular (IM) or subcutaneous (SC) have been absorbed into the body quickly and maximum densities in their blood are achieved within 15 to 30 minutes after injection [8]. The most common route of penicillin injection is intramuscular injection [9].

A study results indicated that when in horses 4400 to 8800 units per kg penicillin procaine in oil with aluminum monostearate are injected, a blood density of penicillin that there are more than $3 \%$ unit penicillin per ml blood's of them and in horses' blood for about 96 hours and in some of them longer stays [10] . Although oil solvent will help produce higher blood levels, but due to its poor physical properties, vast consumption of it, is limited. In addition horses may show acute or chronic adverse tissue reactions for oil solvent in one prescribe of antibiotic. Procaine penicillin in neutralized aqueous sample (with reagents), that there were 300000 units per ml of the substance (penicillin) are available for intramuscular injection is useable. This type of penicillin solution has longer absorption than aqueous solution of it and the therapeutic density in plasma is about 24 hours, but an oil solution and aluminum monostearate have too long delayed absorption. This type of penicillin solution is useful than oil solution of it. Because the residual of oil is not remaining in the tissues. Procaine penicillin $\mathrm{G}$, is composed of one molecule of procainamide and one molecule penicillin and there is a ratio of $15.5 \%$ procainamide and penicillin (the effective substance) of it is 940 units per mg [11]. Thus, in each $\mathrm{ml}$ of solution (suspension) containing 300000 units of penicillin and $125 \mathrm{mg}$ of procainamide [12].

Bronchopneumonia with pathogens invade the lungs caused by breathing air way. In calves of dairy breeds often call this type of pneumonia enzootic pneumonia that for its outbreak in calves, management, infectious and environmental factors are involved $[4,13]$. Environmental and climate change, which will cause more disease outbreak in cold seasons, but it seems the management and infectious disease will have a prominent role in disease and the damages of that. For example, overcrowding, inadequate ventilation, exposure to adult cattle, or lack of nutritional factors has been reported [4]. The aim of this study was to evaluation of procaine penicillin injection in treatment of calves pneumonia..

\section{Material and methods}

In this study, forty crossover calves of 3-6 months of age with an average weight of 60 to $100 \mathrm{~kg}$ with pneumonia were clinically examined. Pneumonia refers to the cases of loss of appetite, depression, increased respiratory rate to more than 50 per minutes, spontaneous cough or in handling of the trachea, and abnormal lung sounds and nasal catarrh. The infected calves were divided into two equal parts: A) The control group was not treated, B) In the experimental group, penicillin 3 million IU was administered as deep intramuscular injection by dose of $50000 \mathrm{IU} / \mathrm{kg}$.

During the treatment phase of patients with pneumonia in control and experimental group, sterile swabs was taken from the lower part of the URT of infected patients, and simultaneous with antibiotic therapy, the taken sterile swabs were undergoes bacteriological examination and types of bacteria was characterized. The bacteria isolated in culture, undergoes antibiotic susceptibility tests by antibiotic discs which were made by control and experimental antibiotics, and thus the inhibition rate of bacteria growth was determined by the disks.

About 4 days after treatment started, cases that were treated in both groups were investigated. The recovery criteria, was including improved respiratory disorders (sounds, discharge, clinical findings), gain complete appetite. Data analysis was performed using SPSS Statistical software (ver. 22).

\section{Results}

Bacteria isolated from nasal swabs of patients and antibiotic susceptibility test (areola size: $\mathrm{mm}$ ) of control and experimental group has been shown in the following table. 
Table 1 Isolated bacteria and antibiotic susceptibility results

\begin{tabular}{|c|c|}
\hline Isolated Bacteria & $\begin{array}{l}\text { Antibiotic susceptibility } \\
\text { test (areola size: } \mathbf{m m} \text { ) }\end{array}$ \\
\hline Nocardia & 45 \\
\hline Moraxella & 28 \\
\hline Moraxella & 25 \\
\hline Moraxella & 28 \\
\hline Eikemella & 28 \\
\hline Moraxella & 33 \\
\hline Bacillus.spp & 38 \\
\hline Staphylococcus caprae & 32 \\
\hline R.egui & 15 \\
\hline Staphylococcus aureus & 50 \\
\hline Moraxella & 30 \\
\hline Staphylococcus saprophyticus & 30 \\
\hline Staphylococcus aureus & 44 \\
\hline Moraxella & 38 \\
\hline Moraxella & 30 \\
\hline Lack of growth & - \\
\hline Staphylococcus epidermidis & 36 \\
\hline Eikemella & 43 \\
\hline Staphylococcus caprae & 40 \\
\hline Staphylococcus epidermidis & 43 \\
\hline Eikemella & 30 \\
\hline Staphylococcus saprophyticu & 5 \\
\hline Branhamella & 30 \\
\hline Moraxella & 40 \\
\hline Nocardia & 36 \\
\hline Staphylococcus epidermidis & 36 \\
\hline Moraxella & 40 \\
\hline Bacillus spp & 50 \\
\hline Corynebacterium & 40 \\
\hline Moraxella & 33 \\
\hline Moraxella & 38 \\
\hline Acitnobacillus & 30 \\
\hline Flavobacterium & 40 \\
\hline Moraxella & 42 \\
\hline Staphylococcus caprae & 15 \\
\hline Staphylococcus aureus & 40 \\
\hline Bacillus.spp & 40 \\
\hline Acinetobacter & 40 \\
\hline Bacillus.spp & 32 \\
\hline Staphylococcus caprae & 40 \\
\hline Brarhamella & 50 \\
\hline Brarhamella & 50 \\
\hline
\end{tabular}


Farkhad Hoshyar et al. / GSC Biological and Pharmaceutical Sciences 2019, 09(01), 110-114

\begin{tabular}{|l|l|}
\hline Staphylococcus caprae & 40 \\
\hline Brarhamella & 50 \\
\hline Staphylococcus aureus & 34 \\
\hline Bacillus.spp & 0 \\
\hline R.egui & 15 \\
\hline Staphylococcus aureus & 29 \\
\hline Staphylococcus caprae & 30 \\
\hline Bacillus.spp & 0 \\
\hline Staphylococcus aureus & 42 \\
\hline Corynebacterium & 30 \\
\hline Staphylococcus caprae & 30 \\
\hline Staphylococcus epidermidis & 40 \\
\hline Bacillus.spp & 22 \\
\hline Staphylococcus epidermidis & 40 \\
\hline Staphylococcus aureus & 32 \\
\hline Nocardia & 20 \\
\hline
\end{tabular}

Results indicated that the 72 percent were recovered from pneumonia after treatment period, and there were not any statistical differences between groups

\section{Discussion}

Infectious agents, including two main groups, one is viruses and the other bacteria. Common viruses are: PI3, IBR and BRSV that in Iran IBR has been reported the most common viral agent. Other viruses may have a lower frequency involved in the pathogenesis [13]. The most important bacteria that play a role in pneumonia include: Mannheimia haemolytica, Pasteurella multocida and Haemophilus somnus pneumonia, which presence of these bacteria in pneumonia lesions of slaughtered cattle around Tabriz and Tehran have also been reported [7]. These bacteria are normal residents of nasal and pharynx mucus, but these bacteria are not found in normal healthy lung and are known as opportunistic microorganism. In poor management and poor weather conditions or respiratory viral infections it will create opportunities for these bacteria [14]. When bacterial agents were deployed in the lungs, alone or with viruses inflammation conditions were developed in lung and finally it cause bronchopneumonia with symptoms that lead to increased body temperature, increased respiratory movements, cough and nasal excretion that consistency of that will vary based on time. In treatments of animals infected with bronchopneumonia, three main goals are considered and include: 1) Removal of invasive bacteria, 2) limiting the inflammatory reaction, 3) Supportive therapy and good nursing. For remove or decrease invasive pathogenic bacteria, the use of antibiotics are inevitable [15].

Therapeutic methods by use of antibiotics almost are based on veterinary experience in local regions rather than on the results of bacterial sensitivity test. Because that test is time consuming and whatever is obtained in the laboratory will be regardless of the immune system function and furthermore, the time is a key criterion in treatment so that early treatment will have a better result. Treatment duration is distinct from antibiotic therapy in gastrointestinal tract. In Pneumonia treatment period was recommended to be 3 to 5 days. However, the antibiotic drug should have tissue penetration and in lung tissue should reach to high density

Researchers constantly have been tried new producing drugs but have not achieved the desired product due to the wonders of life and biology and although these products are good in times. It seems that penicillin procaine injection powder ( 3 million IU) w according to our study results may be effective in the treatment of pneumonia in calves with the effective range.

\section{Compliance with ethical standards}

\section{Acknowledgments}

The author thanks to Tabriz faculty of veterinary medicine of Islamic Azad University. 


\section{Disclosure of conflict of interest}

The authors declare that they have no conflict of interest.

\section{References}

[1] Donovan GA, Dohoo IR, Montgomery DM and Bennett FL. (1998). Calf and disease factors affecting growth in female Holstein calves in Florida, USA. Preventive Veterinary Medicine. 33(1-4), 1-10.

[2] Church, TL and Radostits, OM. (1981). A retrospective survey of diseases of feedlot cattle in Alberta. Can Vet J. 2227-30.

[3] Martin, SW, Meek AH, Davis DG, Thomson RG, Johnson JA, Lopez A, Stephens, L, Curtis RA, Prescott JF, Rosendal S, Savan M, Zubaidy AJ and Bolton, MR. (1980). Factors associated with mortality in feedlot cattle: The Bruce County beef cattle project. Can J Comp Med. 441-10.

[4] Hjerpe CA. (Year). Treatment regimes for feedlot cattle with bronchopneumonia and fibrinous pneumonia. In: 10th Annual Food Animal Medicine Conference, 1984, Columbus, Ohio, 228-255.

[5] Rehm WF and White GA. (1970). Field trial with trimethoprim and sulfadoxine in bacterial diseases of cattle and pigs. Vet Rec. 8739-42.

[6] Richert RM, Cicconi KM, Gamroth MJ, Schukken YH, Stiglbauer KE and Ruegg, PL. (2013). Risk factors for clinical mastitis, ketosis, and pneumonia in dairy cattle on organic and small conventional farms in the United States. J Dairy Sci. 15(13), 00354-8.

[7] Theurer ME, Anderson DE, White BJ, Miesner, MD, Mosier DA, Coetzee JF, Lakritz, J and Amrine, DE. (2013). Effect of Mannheimia haemolytica pneumonia on behavior and physiologic responses of calves during high ambient environmental temperatures. J Anim Sci. 88.

[8] Schipper IA, Filipovs D, Ebeltoft, H and Schermeister LJ. (1971). Blood serum concentrations of various benzyl penicillins after their intramuscular administration to cattle. J Am Vet Med Assoc. 158(4), 494-500.

[9] Brisbane WP. (1963). Antibiotic reactions in cattle. Can. Vet. J. 4(9), 234--235.

[10] Mcconnico RS, Roberts MC and Tompkins M. (1992). Penicillin-induced immune-mediated hemolytic anemia in a horse. J Am Vet Med Assoc. 201(9), 1402-3.

[11] English PB. (1960). Serum penicillin concentrations in sheep after treatment with potassium, procaine and fortified benzathine benzylpenicillins. Austr. Vet. J. 36253-260.

[12] Franklin A, Holmberg O, Horn Af Rantzien M and Astrom G. (1984). Effect of procaine benzylpenicillin alone or in combination with dihydrostreptomycin on udder pathogens in vitro and in experimentally infected bovine udders. Am. J. Vet. Res. 45(7), 1398-1402.

[13] Scott PR. (2013). Clinical presentation, auscultation recordings, ultrasonographic findings and treatment response of 12 adult cattle with chronic suppurative pneumonia: case study. Ir Vet J. 66(1), 5. doi: 10.1186/20460481-66-5.

[14] Brunton LA, Duncan D, Coldham NG, Snow LC and Jones JR. (2012). A survey of antimicrobial usage on dairy farms and waste milk feeding practices in England and Wales. Vet Rec. 171(12), 296. Epub 2012 Aug 18.

[15] Mann S, Siler JD, Jordan D and Warnick LD. (2011). Antimicrobial susceptibility of fecal Escherichia coli isolates in dairy cows following systemic treatment with ceftiofur or penicillin. Foodborne Pathog Dis. 8(8), 861-7. doi: 10.1089/fpd.2010.0751. Epub 2011 Mar 7.

\section{How to cite this article}

Farkhad Hoshyar B, Kkhanzade J and Montazemi P. (2019). The control of clinical pneumonia in calves. GSC Biological and Pharmaceutical Sciences, 9(1), 110-114. 